\title{
The Effect of work Conflict and Job Stress on The Human Resources Performance (Case Study: Maintenance \& Engineer Division at PT. Paiton Operation \& Maintenance Indonesia)
}

\author{
Ni Gusti Made Rai ${ }^{1}$, Nabila Silmina ${ }^{1}$, Helmi Fitrananda ${ }^{1 *}$, Syarifa Hanoum ${ }^{1,2}$, \\ Puti Sinansari ${ }^{1}$, Bustanul Arifin Noor ${ }^{1}$ \\ ${ }^{1}$ Department of Business Management, Institut Teknologi Sepuluh Nopember (ITS) Surabaya, Indonesia \\ ${ }^{2}$ Decision Sciences and Modelling Program, ISILC, Victoria University, Melbourne, Australia \\ *Corresponding author. Email: helmi2015.hp@gmail.com
}

\begin{abstract}
PT. Paiton Operation and Maintenance Indonesia is a business enterprise engaged withinside the subject of steam energy technology and is the most important in Indonesia. In carrying out the company's operations, there are obstacles that can trigger internal conflicts due to a decrease in incentives for employees of the Maintenance and Engineer Division. This makes employees feeling unappreciated, experiencing stress at work, and very little employee involvement.The purpose of this study was to determine the effect of a work conflict and work stress on the performance of the Maintenance and Engineer Division employees at PT. Paiton Operation \& Maintenance Indonesia. Data collection was carried out by distributing online questionnaires with a complete of 107 personnel blended from the Maintenance and Engineer Division. Data analysis in this study used the Partial Least Squares Structural Equation Modeling (PLS-SEM) method of Smart PLS. According to the findings of this research, work conflict has a positive and significant effect on employee performance. The research findings also proved that job stress does not affect employee performance. The results of the study provide recommendations and managerial implications based on the analysis in this study so that the company can implement and prioritize the quality of human resources to maximize employee performance.
\end{abstract}

\section{Keywords: Human Resources, Work Conflict, Job Stress, Employee Performance, PLS-SEM}

\section{INTRODUCTION}

Human sources are one of the company's maximum vital property in strolling its business. states that the company can develop rapidly with the empowerment of very effective resources [1]. Therefore, employee performance must have a very positive trend and avoid negative aspects [2]. The factors that can influence employee performance's positive and negative trends are work conflict and job stress.

PT. Paiton Operation \& Maintenance Indonesia is one of the private companies engaged in Indonesia's largest steam power plant sector. This company was founded to implement the Indonesian government's growth, energy conservation, and diversification policies. Therefore, it is hoped that this power plant can generate and supply electricity for the Javad and Bali areas, with a total capacity of 2045 NMW. PT. Paiton Operation \& Maintenance Indonesia has several power generation units, namely Units 3, 7, and 8 . The size of a company is highly correlated with the number of human resources who are active in carrying out the company's operational activities to achieve the predetermined targets.

In carrying out its operational activities, some obstacles or problems can lead to an internal conflict. The issue arose due to a decrease in incentives for employees in the Maintenance \& Engineer Division. This triggers a misunderstanding which is an employee's distrust of a leader at that time. And also triggers a negative response from every employee who feels unappreciated so that employees experience stress at work, and employee involvement in the Maintenance \& Engineer Division is minimal.

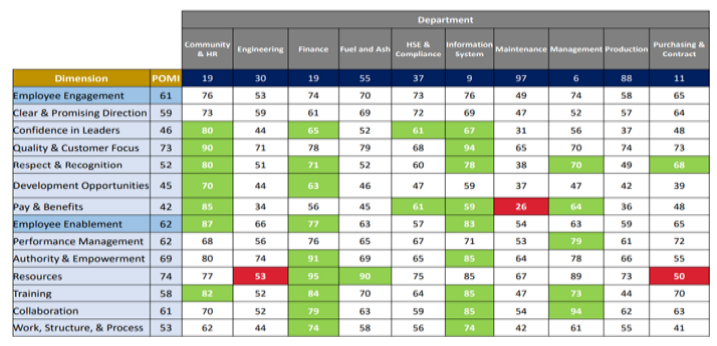

Figure 1. Employee Effectiveness Survey 2019 
Figure 1 shows that the Maintenance and Engineer Division has a minimum score in the "Pay \& Benefits" section, indicating dissatisfaction with its employees' incentives. Then the Maintenance Division also has a minimum score in the "Confidence in Leaders" section. Thus, employee confidence in the Maintenance Division is low due to a decrease in employee incentives, which can cause internal conflicts and stress by employees in carrying out their operations.

This study will focus on testing variables and exploring knowledge about the effects caused by work conflict and work stress on employee performance at the power plant company PT. Paiton Operation \& Maintenance Indonesia in the Maintenance Division. It is hoped that later this research can be useful for management in responding to employee perceptions if there is a dispute between employees or other disputes, then it can reduce work stress for every employee in the company.

\subsection{Research Question}

1. Does Work Conflict affect employee performance?

2. Does work stress affect employee performance?

\subsection{Research Objectives}

1. To test and analyze the relationship between work conflict variables that affect employee performance.

2. To test and analyze the relationship between work stress variables on employee performance.

\section{LITERATURE REVIEW}

In the literature review section, some theories will be used to carry out research related to the variables that this research does, namely work conflict, work stress, and employee performance.

\subsection{Work Conflict}

The conflict has a broad understanding, while conflict is expressed in the form of a relationship between humans who are contradictory or opposed to other parties [3]. Entering the world of work, can not be separated from problems that can trigger a conflict as for the form of conflict, namely work conflict and conflict from family problems. Work conflict can indirectly hurt the relationship between the individual or group [4].

Based on the indicators, work conflict is divided into two, namely functional conflict and dysfunctional conflict [5], [6]. The functional conflict focuses on achieving goals that are done positively, both individually and in groups. On the other hand, dysfunctional conflict is a negative conflict and interferes with or hinders achieving specific goals [6].

\subsection{Job Stress}

In the world of work, it is not uncommon for employees to experience stress in doing their jobs. Work stress is a change in a deviant mindset regularly, leading to mental disorders in every employee's psychological and emotional aspects [7]. If stress has reached the peak of an employee who is experiencing this, it will have an impact on the employee's performance which will decrease, lose the ability to work, and cannot decide on his work [4].

There are three indicators of job stress that can affect an employee's performance in carrying out his work in a company or organization [7]. Role ambiguity is where an employee is in a stage of confusion in carrying out their duties. Underutilization of skills where skills are underutilized, while work overload is the inability of employees to carry out their duties due to having excessive responsibilities and not following their abilities [7].

\subsection{Performance Employee}

Employee performance is the output of an employee who has made a contribution to the company regarding involvement in carrying out their duties and the company has appreciated the employee is productive or counterproductive behavior [7]. Performance is a very important part for companies, where companies need employees who have very high performance to achieve company goals and increase productivity [8]. The three indicators [8] are task performance, one's ability to carry out their duties, contextual performance is behavior that is outside the work context to improve performance in the work environment, counterproductive behavior is negative behavior through an worker in wearing out their duties [9].

\subsection{Research Hypotheses}

The research hypothesis can be formulated as follows:

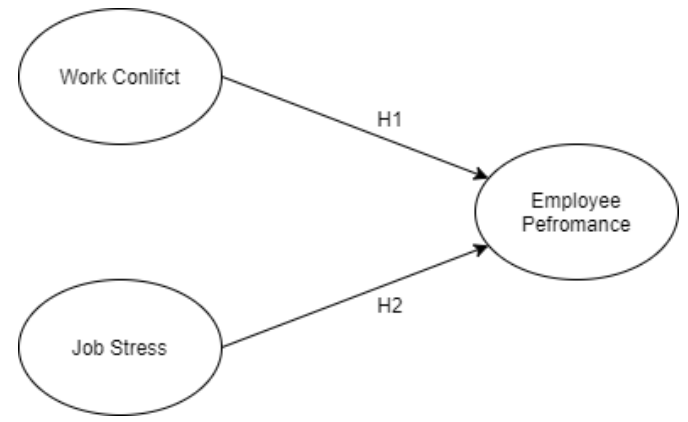

Figure 2. Research Hypotheses 
1. H1. Work conflict has a positive effect on employee performance.

2. H2. Job stress affects employee performance.

\section{METHODOLOGY}

This research is explanatory research to determine the cause and effect between research variables following the research hypothesis design [10]. This research was conducted through the distribution of online questionnaires to respondents. Respondents in this study were all employees of the Maintenance and Engineer Division, as many as 147 employees. Sampling was carried out using the slovin method. Therefore the sample of this study amounted to 107 employees of the combined Maintenance \& Engineer Division with a margin of error of 5\%.

This studies questionnaire is split into 4 parts: the primary component (position, gender, age, closing education, and years of labor), the second one component is a assertion of labor battle variables with a complete of four statements from 2 signs withinside the study [6], the third phase carries a assertion of labor pressure variables with a complete of 6 statements of three signs withinside the study [7], the fourth phase carries 6 statements of three signs of worker overall performance variables [8]. Then the records evaluation become completed through the use of Structure Equation Model (SEM) with Partial Least Square (PLS) approach.

\section{RESULT AND DISCUSSION}

This section will explain the results of data processing and analysis as well as managerial implications for the company following the results in this study.

\subsection{Demographic Respondent}

The collection of questionnaires was carried out from June 3 to June 30, 2021 with 107 combined employees of the Maintenance \& Engineer Division as respondents.

\section{Table 1. Demographics of Respondents by Position}

\begin{tabular}{|c|c|c|}
\hline Position & Frequency & Percent \\
\hline Maintenance & 82 & $77 \%$ \\
\hline Engineer & 25 & $23 \%$ \\
\hline Total & 107 & $100 \%$ \\
\hline
\end{tabular}

Respondents who participated in filling out the questionnaire were divided into the Maintenance and Engineer Division, of which the most were from the Maintenance Division.
Table 2. Demographics of Respondents Based on Years of Service

\begin{tabular}{|c|c|c|}
\hline $\begin{array}{c}\text { Years of } \\
\text { Service }\end{array}$ & Frequency & Percent \\
\hline$<4$ Years & 24 & $22 \%$ \\
\hline $5-9$ Years & 16 & $15 \%$ \\
\hline $10-14$ Years & 16 & $15 \%$ \\
\hline$>15$ Years & 51 & $48 \%$ \\
\hline Total & 107 & $100 \%$ \\
\hline
\end{tabular}

Based in this table, maximum respondents have labored for $>15$ years, this indicates worker loyalty to the company. The results from another demographic analysis are prominent respondents were male (94\%), with an age range of 25-39 years (45\%), the last education $\mathrm{S} 1(50 \%)$.

\subsection{Convergent Validity and Composite Validity}

Table below summarise convergent validity and composite validity.

Table 3. Convergent Validity and Composite Validity

\begin{tabular}{|c|c|c|}
\hline Variable & $\begin{array}{c}\text { Composite } \\
\text { Realibility }\end{array}$ & AVE \\
\hline Work Conflict & 0,826 & 0,614 \\
\hline Job Stress & 0,801 & 0,507 \\
\hline $\begin{array}{c}\text { Employee } \\
\text { Performance }\end{array}$ & 0,842 & 0,518 \\
\hline
\end{tabular}

Overall, the AVE value of each variable has exceeded 0.5 which indicates the measurement is valid (Hair et al., 2016). Then the results of the composite reliability value with 0.7 means it is acceptable, if 0.8 then it can be said to be very satisfying [12].

\subsection{Cofficient of Determination $\left(R^{2}\right)$}

The value of $\mathrm{R}$ square as the basis for measuring the level of accuracy model on research.

Table 4. $R$ Square

\begin{tabular}{|c|c|c|}
\hline $\begin{array}{c}\text { Variable } \\
\text { Dependent }\end{array}$ & R Square & Impact \\
\hline $\begin{array}{c}\text { Employee } \\
\text { Peformance }\end{array}$ & 0,432 & Moderate \\
\hline
\end{tabular}

The table above indicates that value of $\mathrm{R}$ Square is 0.432 . This explains that worker overall performance variables may be defined with the aid of using paintings 
war and paintings strain variables with a percent of $43.2 \%$ with a slight influence, at the same time as the relaxation of the $56.8 \%$ percent may be defined with the aid of using different elements outdoor of this study. $\mathrm{R}$ Square fee $>0,67$ is strong, $>0,33$ is slight, $>0.19$ is weak [13].

\subsection{Hypotheses Testing}

The following are the results of the relationship between variables that have been developed in this study.

Table 5. Hypotheses Testing

\begin{tabular}{|c|c|c|c|c|c|}
\hline \multicolumn{2}{|c|}{ Variable relationship } & $\begin{array}{c}\text { T } \\
\text { Statis } \\
\text { tic }\end{array}$ & $\begin{array}{c}\text { P- } \\
\text { value }\end{array}$ & $\begin{array}{c}\text { Re } \\
\text { ma } \\
\text { rk }\end{array}$ \\
\hline $\begin{array}{c}\text { Work } \\
\text { Conflic } \\
\mathrm{t}\end{array}$ & $\rightarrow$ & $\begin{array}{c}\text { Employee } \\
\text { Performan } \\
\text { ce }\end{array}$ & 9,548 & 0,000 & $\begin{array}{c}\mathrm{H} 1 \\
\text { Acc } \\
\text { epte } \\
\mathrm{d}\end{array}$ \\
\hline Job & $\rightarrow$ & $\begin{array}{c}\text { Employee } \\
\text { Performan } \\
\text { Stress }\end{array}$ & 0,933 & 0,013 & $\begin{array}{c}\mathrm{H} 2 \\
\text { Act } \\
\text { Act } \\
\text { epte } \\
\mathrm{d}\end{array}$ \\
\hline
\end{tabular}

The relationship among variables may be enormous if every indicator's t-statistic cost is extra than the tstatistical desk 1.96. P-value of all variable signs is below 0.05 [12]. Work conflict on worker overall performance has a fine course coefficient with a fee of 0.679 , and the $\mathrm{T}$ statistic is extra than the provision. Then it has $\mathrm{P}$ Values much less than 0.05 in order that speculation 1 may be accepted. The outcomes of this examine are in step with preceding studies conducted [6], which showed that work conflict in a company can be conditioned well, then the level of employee work effectiveness will increase.

Hypotheses 2 states that work conflict has a positive effect on employee performance. The variable work stress on employee performance has a positive path coefficient of 0.090 but the value of the $T$ statistic is less than the existing requirements, which is only 0.933 and the $\mathrm{P}$ Values are less than 0.05. So hypothesis 2 is rejected which can be stated that work stress does not affect employee performance. This end result isn't always in keeping with the preceding studies [7] which states that the variable of job stress has a significant relationship to employee performance, this indicates that in a job in an indication of stress can significantly affect the performance of the employee.

\subsection{Managerial Implication}

The results of research findings indicate that the functional conflict dimension is significant to work conflict and work conflict affects employee performance. Functional conflict is more supportive of a person to achieve group and personal goals. The program is called employee gathering and sharing sessions. Employee gatherings can be held once a year with the aim of bonding togetherness among employees. Then, sharing sessions are held regularly every month to provide mutual support and advice regarding work.

The findings of this study indicate that the task performance dimension significantly affects employee performance. The company supports the provision of programs for self-development such as certification and undergraduate schools. Pre-selection is carried out on each employee who wants to take part in the program according to their field. Then the selected employee will be given a direct program and must serve the company at a certain time for at least 5 years.

Based on research findings show that the contextual performance dimension significantly affects employee performance. Companies can provide training on leadership to have adequate competence as a leader. The program can be implemented for employee leaders with an age range of 25-39 years so that they have competence as leaders. Then work compensation if you provide innovation and work overtime or are on call out, the compensation program also needs to be prepared and researched further to suit the needs of each employee.

\section{CONCLUSION}

The outcomes of the take a look at of the paintings warfare speculation have a advantageous and tremendous impact on overall performance that these findings have been proven and can be accepted. This finding is also in line with prior research [3], which states that in functional conflict, the source of conflict can be managed properly and can positively impact the organization. With good working conflict conditioning from every employee in the Maintenance and Engineer Division, it can positively influence each co-workers to strengthen the relationship between co-workers.

The results of the study of the hypothesis that job stress affects employee performance, the findings in this study mean that the hypothesis is rejected. The study result is in line with previous study [4], which states that work conflict does not significantly affect employee performance and indicates that high or low work stress cannot affect employee performance. Work stress does not affect the performance of employees in the Maintenance and Engineer Division because employees have work commitments in carrying out every responsibility they have received it is also shown in the descriptive findings of the tenure of employees who have more than 15 years of service which indicates that employees have a high sense of loyalty to the company. 


\section{ACKNOWLEDGMENTS}

This research was supported by Department of Business Management, Faculty of Creative Design and Digital Business, Institut Teknologi Sepuluh Nopember, Surabaya, Indonesia, and PT. Paiton Operation \& Maintenance Indonesia, Probolinggo, Indonesia.

\section{REFERENCES}

[1] C. Julvia, "PENGARUH STRES KERJA DAN KONFLIK KERJA TERHADAP KINERJA KARYAWAN," J. Ilm. Manaj. BISNIS, vol. 16, no. 1, pp. 59-72, 2016.

[2] M. E. Karabay, B. Akyüz, and M. Elçi, "Effects of Family-Work Conflict, Locus of Control, Self Confidence and Extraversion Personality on Employee Work Stress," Procedia - Soc. Behav. Sci., vol. 235, no. October, pp. 269-280, 2016, doi: 10.1016/j.sbspro.2016.11.030.

[3] M. R. Anwari, B. S. Sunuharyo, and I. Ruhana, "KARYAWAN ( Studi pada Karyawan PT Telkomsel Branch Malang )," vol. 41, no. 1, pp. 1-10, 2016.

[4] R. B. Kurniawan, R. A. Sularso, and P. Titisari, "The Effect Of Work Conflict And Job Stress On Employees Performance With Organizational Commitment As Intervening Variable," J. Manaj. Dan Kewirausahaan, vol. 6, no. 1, pp. 1-8, 2018, doi: 10.26905/jmdk.v6i1.1985.

[5] Pujaatmaka, Manajemen Sumber Daya Manusia Untuk Perusahaan. Jakarta: PT. Raja Grafindo Persada, 2006.

[6] M. Putri, "PENGARUH SEMANGAT KERJA DAN KONFLIK KERJA TERHADAP EFEKTIVITAS KERJA KARYAWAN PADA PT. SURYA BRATASENA PLANTATION PELALAWAN," JOM Fekon, vol. 4, no. 1, pp. 376-386, 2017.

[7] R. Jalagat, "Determinants of Job Stress and Its Relationship on Employee Job Performance," Am. J. Manag. Sci. Eng., vol. 2, no. 1, p. 1, 2017, doi: 10.11648/j.ajmse.20170201.11.

[8] T. Widyastuti and R. Hidayat, "Adaptation of Individual Work Performance Questionnaire (IWPQ) into Bahasa Indonesia," Int. J. Res. Stud. Psychol., vol. 7, no. 2, pp. 101-112, 2018, doi: 10.5861/ijrsp.2018.3020.

[9] S. J. Montowidlo, "Job performance," in Handbook of psychology: Industrial and organizational psychology, USA: John Wiley \& Sons, 2003, pp. 39-52.

[10] Sugiyono, Metode Penelitian Kuantitatif Kualitatif dan R\&B. Bandung: Alfabeta, 2012.
[11] J. F. Hair, G. M. Hult, C. M. Ringle, and M. Sarstedt, A Primer on Partial Least Squares Structural Equation Modeling (PLS-SEM). Los Angeles: SAGE Publications, 2016.

[12] J. Henseler, C. M. Ringle, and R. R. Sinkovics, "The use of partial least squares path modeling in international marketing," Adv. Int. Mark., vol. 20, no. 2009, pp. 277-319, 2009, doi: 10.1108/S1474-7979(2009)0000020014.

[13] W. W. Chin, B. L. Marcelin, and P. R. Newsted, "A partial least squares latent variable modeling approach for measuring interaction effects: Results from a Monte Carlo simulation study and an electronic-mail emotion/adoption study," Inf. Syst. Res., vol. 14, no. 2, 2003, doi: 10.1287/isre.14.2.189.16018. 